\author{
Aldona Wiktorska-Święcka
}

\title{
PROCESS TRACING IN EVALUATING INNOVATION IN SUB-REGIONAL GOVERNANCE. CASE STUDY OF SELECTED INTEGRATED TERRITORIAL INVESTMENTS IN POLAND ${ }^{1}$
}

\author{
DOI: $10.1515 /$ ppsr-2015-0040
}

\begin{abstract}
Author
Aldona Wiktorska-Święcka, Ph.D, Prof. of University of Wrocław, political scientist, economist, Germanist. Main fields of interests: public governance and public policy (dynamic approach upon globalization and Europeanisation); territorial governance (regional, urban, metropolitan governance); sectoral governance (social policy, educational policy, cultural policy, labour market policy, civic-public partnership, public-private partnership, cross-sectoral partnerships); innovation in management and governance (social responsibility of an organization, diversity management, corporate citizenship, social innovation, social investment); normative assumptions of management and governance: democratization, ethics in management, quality in management, good governance, values and compliance, democratic organizational culture, civil society, participatory governance, social and human capital, leadership).
\end{abstract}

e-mail: aldona.wiktorska-swiecka@uwr.edu.pl

\begin{abstract}
Integrated Territorial Investments (ITIs) are a new integration tool that binds the thematic objectives defined operational programmes with the territorial dimension. Due to their formula, ITIs may be seen as a kind of innovation in sub-regional governance. The European Commission considers them as an opportunity to introduce solutions that can be effective in facing the challenges of contemporary development on a supra-local scale. Accordingly, they should be regarded as a possibility for Member States to activate innovative governance arrangements that will allow for the implementation of projects, which-depending on the country-more or less reflect issues indicated by the Commission as a priority.

In Poland, the Integrated Territorial Investments are implemented in 24 functional areas. Due to a new approach to cities and their role in development processes in the country, they can mean a new opening for the urban policy and urban development. Concentrating on innovative governance arrangements, the aim of this paper is to analyze selected case studies of 4 ITIs implemented by large (more than 500,000 inhabitants) provincial cities: Wrocław, Łódź, Gdańsk, Katowice, which are capitals of regions in which one defined a different development potential. The analysis will allow the formulation of answers to the following research questions:

- Are there any innovative governance arrangements indicated during ITIs implementation?

- What are the implemented modes of sub-regional governance?

- What is the role and importance of institutional actors in the process of ITIs governance?

- What are their new competences linked to the ITIs implementation?

- Are there any new products/services related to innovation in sub-regional governance?

- Do ITIs consider principles of "good governance" a one of key factors of innovation in governance?
\end{abstract}

1 This publication is a part of research conducted within a project funded by the National Science Centre (Polish: Narodowe Centrum Nauki, NCN), based on the NCN decision no. UMO-2013/09/B/ HS5/04522. Special appreciation and thanks to my co-researchers Małgorzata Michalewska-Pawlak and Monika Klimowicz from University of Wrocław. 
The paper contains key definitions and points out processes related to the transition of modes of governance at the sub-regional level. It also indicates further challenges in Polish territorial development upon Europeanisation.

Keywords: ITIs - sub-regional governance-Europeanisation-innovative governance arrangements - development of functional areas

\section{Introduction}

Integrated Territorial Investments (ITIs) are a new integration tool that combines the thematic objectives defined in operational programmes with the territorial dimension. They can be analyzed as the emergence of urban governance phenomena itself and a possible shift form administrative government to more open to different local actors' decision making system which demands cooperation between local public authorities and other local or regional private and civic organizations. From this point of view, due to their formula, ITIs may be considered as an innovation in governance. Interest in the question of innovation in governance has its sources in the rising challenges and problems associated with the effectiveness of the functioning of the public sector as well as attempts to overcome them by creating and implementing new steering solutions in the public sector. ITIs incorporate different forms of inter-communal cooperation, associations and agreements that were established in different European agglomerations as a result of Europeanisation. Regarding this, one can witness a shift of the focus: from a policy referring to the entire territory (region or state) to what is key to the development of sub-regions, i.e. urban centres and functional areas around them (metropolitan and functional areas). ITIs represent important characteristics of the governance approach. In this sense one can mention a new political culture that provides for flexible and responsive administration, structural participation of citizens (clients, users of the city) and decentralised decision-making mechanisms. Thus, it requires the formulation and implementation of an urban policy which comprises the economic, social and spatial spheres, and which takes into account an integrated approach to development.

The European Commission treats ITIs as an opportunity to introduce solutions that can be effective in responding to the challenges of contemporary development on a sub-regional scale (Klimowicz, Dudzik, 2015). They can be regarded as a possibility for Member States to activate innovative governance arrangements that will make it possible to implement projects which-depending on the country-more or less reflect issues indicated by the Commission as priorities.

Accordingly to the approach of $\mathrm{H}$. Anheier and S. Korreck, who defined innovations in governance "... as novel rules, regulations, and approaches that, compared to the current state of affairs, seek to address a public problem in more efficacious and effective ways, to achieve better policy outcomes, and, ultimately, to enhance legitimacy" (Anheier, Korreck, 2013, p. 83), this study identifies innovative solutions for sub-regional governance in Poland. Therefore, the performed evaluation focuses primarily on the following:

- determining whether solutions being implemented in the selected functional areas can be defined as "innovations in governance"; 
- establishing which of the institutional arrangements observed are defined as "innovations in governance" by the stakeholders involved in the process of ITI development and implementation;

- verifying what competences and procedures facilitate progress in actions taken to generate and implement innovations in sub-regional governance;

- analysing the interventions undertaken with regard to their beneficiaries' needs and expectations; and

- identifying problems and their causes.

Nowadays territorial governance can be regarded as one of the public administration's most complex challenges: it is a kind of balancing act between not only the competing priorities and needs of various stakeholders, but also between the often diverging visions of the role of public administration and public governance as such. It is a concept which does not fit in with the traditional patterns of thinking about the public sector and its actions, especially in the face of the current challenges regions have to face as well as the resources they have at their disposal. In addition, today both "territories" and their "governance" must be approached from the perspective of integrating these variables, both in the systemic-institutional approach (indicating practice as it is with regard to functional areas and their governance) and the normative approach (indicating the desired, i.e. the right practice in this respect). In Poland, the Integrated Territorial Investments are implemented in 24 functional areas. Due to a new approach to cities and their role in development processes in the country, they can mean a new opening for urban policy and urban development. To fulfil the purposes of this paper, it was decided to consider following ITIs:

- Integrated Territorial Investments in the Metropolitan Area of Gdańsk-Gdynia-Sopot (ITI MA GGS);

- Integrated Territorial Investments of the Łódź Metropolitan Area Association (ITI ŁMAA);

- Integrated Territorial Investments in the Wrocław Functional Area (ITI WFA);

- Integrated Territorial Investments in the Central Sub-region of Silesia (ITT CSS).

In order to determine to what extent institutional practice can be regarded as innovative, the adoption a model that will help to verify it was required. The selection of ITIs for further analyses refers to a theoretical model of innovation in governance developed within a study conducted under the project funded by the National Science Centre (Scheme 1). This model takes into account network- and partnership-based systems of relations as well as division of roles and obligations among stakeholders and the stakeholders' impact on the decisions taken. It assumes the generation of various types of innovative solutions in governance, e.g.

- institutional innovations, which focus on changing the profile of the existing institutions and / or establishing new ones;

- organisational innovations, which are associated with the introduction of new steering procedures and techniques;

- processual innovations, which focus on improving the quality of the public services provided; or

- conceptual innovations, which focus on the introducing of new forms of steering.

This model of innovations in governance considers also: 
- political control: strategic steering by political and administrative leaders; clear rules of financing; flexible organisational structure; decentralisation, greater autonomy of the public administration, cooperation between formal units;

- processes: concentration on outcomes, evaluation and assessment of actions (completed and still in progress);

- professionalism and organisational development: expanding the leadership's competences and responsibilities, improving qualifications and competences; career and professional development planning;

- relations with stakeholders: improving relations with citizens through marketing and improvement in the quality of governance; concentration on service users, their needs and expectations; on promoting competition among service providers and transferring control to communities in the functional area; on decentralising power and introducing participatory governance (Wiktorska-Święcka et al., 2017a; 2017b).

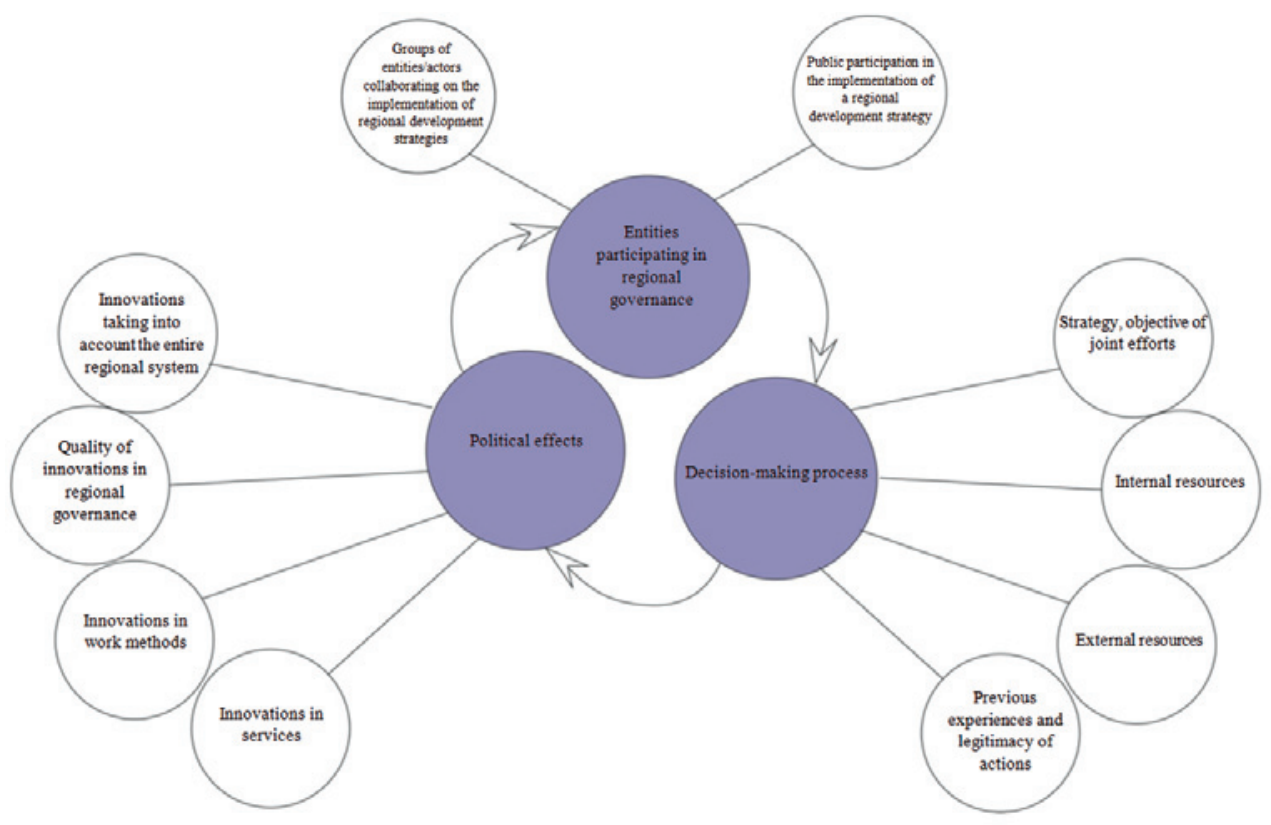

Scheme 1: Model of innovation in governance

Source: Own elaboration, in: Wiktorska-Święcka et al., 2017a; $2017 b$.

The model is characterised by a number of detailed indicators and possible institutional arrangements (Table 1). 
Table 1. Characteristics of the model of innovations in sub-regional governance

\begin{tabular}{|c|c|c|c|}
\hline $\begin{array}{l}\text { Analytical di- } \\
\text { mension }\end{array}$ & Main features & Indicators & Institutional arrangements \\
\hline \multirow[t]{4}{*}{$\begin{array}{l}\text { Entities partici- } \\
\text { pating in region- } \\
\text { al governance }\end{array}$} & \multirow{3}{*}{$\begin{array}{l}\text { Groups of } \\
\text { entities/actors: } \\
\text { individuals/ } \\
\text { units and } \\
\text { organisations } \\
\text { collaborating on } \\
\text { the implementa- } \\
\text { tion of regional } \\
\text { development } \\
\text { strategies }\end{array}$} & $\begin{array}{l}\text { Constellation of groups of } \\
\text { entities/actors and their role in } \\
\text { regional governance: deciding } \\
\text { who and how takes part in deci- } \\
\text { sion-making bodies and how }\end{array}$ & $\begin{array}{l}\text { Clusters, networks, labora- } \\
\text { tories }\end{array}$ \\
\hline & & $\begin{array}{l}\text { Leadership roles: Identification } \\
\text { of leaders }\end{array}$ & $\begin{array}{l}\text { Leadership styles, deci- } \\
\text { sion-making bodies } \\
\text { Formal and informal leaders }\end{array}$ \\
\hline & & $\begin{array}{l}\text { Mutual obligations of entities/ } \\
\text { actors: motivation factors and } \\
\text { reasons behind involvement }\end{array}$ & $\begin{array}{l}\text { Formal regulations } \\
\text { Informal and non-formal } \\
\text { sets of norms and values }\end{array}$ \\
\hline & $\begin{array}{l}\text { Public partic- } \\
\text { ipation in the } \\
\text { implementation } \\
\text { of regional } \\
\text { development } \\
\text { strategies }\end{array}$ & $\begin{array}{l}\text { Public participation: no partic- } \\
\text { ipation, semblance of participa- } \\
\text { tion, information, consultation, } \\
\text { partnership, empowerment } \\
\text { openness of regional authori- } \\
\text { ties, inclusion in/exclusion from } \\
\text { work on the implementation of } \\
\text { regional development strategies }\end{array}$ & $\begin{array}{l}\text { Participation tools: meet- } \\
\text { ings, debates, roundtables, } \\
\text { brainstorming, e-partic- } \\
\text { ipation (online forums, } \\
\text { blogs), deliberation panels, } \\
\text { charettes, open space, future } \\
\text { games, "Planning for Real", } \\
\text { "Word Café" } \\
\text { grassroots movements, cit- } \\
\text { izens' initiatives, non-gov- } \\
\text { ernmental organisations, }\end{array}$ \\
\hline \multirow[t]{3}{*}{$\begin{array}{l}\text { Decision-mak- } \\
\text { ing process }\end{array}$} & \multirow[t]{3}{*}{$\begin{array}{l}\text { Strategy: ob- } \\
\text { jectives of joint } \\
\text { efforts }\end{array}$} & $\begin{array}{l}\text { Shaping the strategy: formulat- } \\
\text { ing shared visions, objectives } \\
\text { and priorities }\end{array}$ & $\begin{array}{l}\text { Scope, methods and partici- } \\
\text { pating entities } \\
\text { Results of consultations } \\
\text { Degree of taking stakehold- } \\
\text { ers' opinions into account } \\
\text { Other forms of dialogue }\end{array}$ \\
\hline & & $\begin{array}{l}\text { Assessment of implementation } \\
\text { possibilities: assessment of sup- } \\
\text { port for and threats to strategy } \\
\text { implementation }\end{array}$ & $\begin{array}{l}\text { Evaluations, including } \\
\text { ex-ante, SWOT } \\
\text { political majority } \\
\text { taking minorities' opinion } \\
\text { into account } \\
\end{array}$ \\
\hline & & $\begin{array}{l}\text { Understanding of strategic de- } \\
\text { velopment objectives: assessment } \\
\text { of the stakeholders' familiarity } \\
\text { with the strategic objectives } \\
\text { (cognitive component, i.e. } \\
\text { knowledge of the objectives, evo- } \\
\text { lutive component, i.e. acceptance } \\
\text { of the strategic objectives) } \\
\text { Acceptance of the strategic } \\
\text { objectives and ways of achieving } \\
\text { them }\end{array}$ & $\begin{array}{l}\text { Consensus } \\
\text { Trade-off } \\
\text { Conflict }\end{array}$ \\
\hline
\end{tabular}




\begin{tabular}{|c|c|c|}
\hline \multirow[t]{4}{*}{$\begin{array}{l}\text { Internal re- } \\
\text { sources: capacity } \\
\text { to satisfy needs } \\
\text { with the region's } \\
\text { own resources }\end{array}$} & $\begin{array}{l}\text { Funds and related resources: } \\
\text { shaping the regional develop- } \\
\text { ment budget } \\
\text { Non-financial resources used in } \\
\text { the pursuit of strategic objectives }\end{array}$ & $\begin{array}{l}\text { Budget } \\
\text { Regional and local pub- } \\
\text { lic-private partnerships, } \\
\text { public-social-private } \\
\text { partnerships, public-social } \\
\text { partnerships } \\
\text { Delegation of tasks } \\
\text { Types of investments }\end{array}$ \\
\hline & $\begin{array}{l}\text { Information and expertise: ac- } \\
\text { quisition of knowledge that will } \\
\text { help with achieving success }\end{array}$ & $\begin{array}{l}\text { Expert analyses } \\
\text { Research (quantitative and } \\
\text { qualitative) } \\
\text { Expert panels }\end{array}$ \\
\hline & $\begin{array}{l}\text { Power and legitimacy: assess- } \\
\text { ment of the involvement of } \\
\text { groups and their inclusion in the } \\
\text { shaping of regional development }\end{array}$ & $\begin{array}{l}\text { Committees, councils, bod- } \\
\text { ies and their impact } \\
\text { Legislative process } \\
\text { Scope of formal competence } \\
\text { Methods for implementing } \\
\text { tasks } \\
\text { Varied local partnership } \\
\text { methods } \\
\text { Coordination mechanism } \\
\end{array}$ \\
\hline & $\begin{array}{l}\text { Legal, political and cultural } \\
\text { environment }\end{array}$ & $\begin{array}{l}\text { Other resources making } \\
\text { participation in the deci- } \\
\text { sion-making process pos- } \\
\text { sible, e.g. cultural compe- } \\
\text { tence, support and political } \\
\text { authority... }\end{array}$ \\
\hline \multirow{2}{*}{$\begin{array}{l}\text { External re- } \\
\text { sources: capacity } \\
\text { to satisfy needs } \\
\text { with resources } \\
\text { acquired from } \\
\text { outside the } \\
\text { region }\end{array}$} & $\begin{array}{l}\text { Impact of the supranational } \\
\text { level: Ensuring support from the } \\
\text { supranational level }\end{array}$ & $\begin{array}{l}\text { Top-down Europeanisation } \\
\text { Bottom-up Europeanisation } \\
\text { Supraregional lobbying } \\
\text { Horizontal Europeanisation }\end{array}$ \\
\hline & $\begin{array}{l}\text { Impact of the national level: en- } \\
\text { suring support from the national } \\
\text { level }\end{array}$ & $\begin{array}{l}\text { Top-down impact of the } \\
\text { national level on the region } \\
\text { Impact of the region on the } \\
\text { national level } \\
\text { Horizontal cooperation of } \\
\text { Polish regions }\end{array}$ \\
\hline $\begin{array}{l}\text { Previous experi- } \\
\text { ences: capacity } \\
\text { to act on the } \\
\text { regional, sub-re- } \\
\text { gional, national } \\
\text { and European } \\
\text { level }\end{array}$ & $\begin{array}{l}\text { Main objectives of regional } \\
\text { activity: drawing on previous } \\
\text { experiences } \\
\text { Number and intensity of cooper- } \\
\text { ation initiatives }\end{array}$ & $\begin{array}{l}\text { Projects implemented in } \\
\text { partnership } \\
\text { Legislative changes favour- } \\
\text { ing decentralisation of the } \\
\text { management of regional } \\
\text { development } \\
\text { Competence changes in the } \\
\text { management of regional } \\
\text { development } \\
\text { Changes in rules of financ- } \\
\text { ing regional development } \\
\text { Permanence of partnerships }\end{array}$ \\
\hline
\end{tabular}




\begin{tabular}{|c|c|c|c|}
\hline \multirow[t]{4}{*}{ Political effects } & $\begin{array}{l}\text { Innovations } \\
\text { taking into ac- } \\
\text { count the entire } \\
\text { regional system }\end{array}$ & $\begin{array}{l}\text { Integration: links between } \\
\text { authorities operating on various } \\
\text { levels of territorial governance }\end{array}$ & $\begin{array}{l}\text { Joint strategies, pro- } \\
\text { grammes, projects (e.g.: } \\
\text { macro-regional strategies) } \\
\text { Implementation monitoring }\end{array}$ \\
\hline & $\begin{array}{l}\text { Innovations in } \\
\text { services }\end{array}$ & $\begin{array}{l}\text { New services } \\
\text { New ways of providing existing } \\
\text { services }\end{array}$ & $\begin{array}{l}\text { Services for enterprises from } \\
\text { rural areas } \\
\text { New environmental protec- } \\
\text { tion solutions } \\
\text { Service assurance systems }\end{array}$ \\
\hline & $\begin{array}{l}\text { Innovations in } \\
\text { products }\end{array}$ & $\begin{array}{l}\text { New products } \\
\text { New ways of delivering products }\end{array}$ & Co-production \\
\hline & $\begin{array}{l}\text { Quality of } \\
\text { innovations in } \\
\text { regional govern- } \\
\text { ance }\end{array}$ & $\begin{array}{l}\text { Participatory governance } \\
\text { "Good governance" }\end{array}$ & $\begin{array}{l}\text { Civil subjectivity } \\
\text { Smart development Sustain- } \\
\text { able development } \\
\text { Increased effectiveness of } \\
\text { actions }\end{array}$ \\
\hline
\end{tabular}

Source: Own elaboration based on [Wiktorska-Święcka et al., 2017a; 2017b.

\section{Methodology}

The study implements the process tracing method, a fundamental tool of qualitative analysis which supports the examination of selected evidence in the light of research questions and hypotheses posed by the investigators (Collier, 2011). Process tracing supports the analysis of cause-and-effect links identified in research. These links "connect the independent variable and the outcomes, therefore must be divided into smaller steps; then the investigator looks for observable evidence of each step" (Van Evera, 1997, p. 64). Thus, process tracing essentially resembles a criminal investigation with evidence being evaluated against each component of the causal mechanism. A. L. George and A. Bennett (2005) believe causal mechanisms to be "physical, social or psychological processes". Under those processes, in specific contexts and conditions, some entities transfer "energy, information or matter" to other entities. In so doing, some of the affected entity's "characteristics, capacities or propensities" are changed in ways that persist until subsequent causal mechanisms act upon it (p. 137).

The study subscribes to the post-positivist paradigm, which assumes the existence of multiple realities and no access to reality independent of the investigator's mind (the investigator and the object of study are interactively linked, so that findings emerge within the context of the situation which shapes the interaction). That is why process tracing, as a research method used for in-depth study, refers to selectively chosen issues that are not representative but may provide significant information (Sale et al. 2002, p. 45). It needs to be noted at this point that, while developing the assumptions of the process tracing approach, a decision had to be made as to which of the possible types of the method to choose as be most relevant one. The literature distinguishes between three possible process tracing methods. These can be used for:

- theory-testing;

- theory-building; or

- explaining outcome (Beach, Pedersen 2013, p. 3). 
In this paper the theory-building approach has been implemented. This distinctive option of process tracing seeks to generate a theory reflecting causal mechanisms based on analysis of empirical evidence from a specific case study (Fitzpatrick et al., 2011). The ambitious goal behind this approach is to make some universal generalisations applicable to interventions to explain the relation between the cause (A) and the outcome (B).

Each of the selected case studies was analysed with regard to the five-step procedure as proposed by M. Punton and K. Welle (2015b):

- Collecting and developing the study material: the stage involved the collection of study material to be used for formulating the study hypotheses. The empirical material thus obtained was elaborated by indicating the links between causes and outcomes;

- Data analysis and formulating a hypothetical causal mechanism: the task at that stage was to develop robust empirical tests to find out whether or not all the components of the causal mechanisms were present. This involved detecting manifestations, i.e. making specified predictions as to what evidence could be expected if a hypothesised component of the mechanism existed. Each component of the mechanism could thus become a hypothesis to be tested. The logic of the empirical tests in process tracing was that if we expected $A$ to give rise to $B$, each component of the mechanism between A and B should be reflected in the empirical material (expected evidence);

- Operationalising the causal mechanism: at this stage, evidence was identified for the existence of causal links between the various components of the mechanism. This required a way of thinking that took into account credible alternative explanations. These proved instrumental in explaining the components of the mechanism and observing their manifestations;

- Assessing the inferential weight of the evidence: the key task at this stage was to check the validity of the hypotheses assumed by testing ("weighing") the evidence collected. This was done by grouping the sources according to the essential nature of a source and strength of evidence provided by that source. The tests performed - straw-in-thewind, hoop, smoking gun and doubly-decisive tests - are all based on the uniqueness and certainty principles (Punton, Welle, 2015a);

- Conclusions from process tracing: in order to determine a mechanism, the most important existing elements, processes and outcomes should be observed and analysed when building the theory with particular focus on fidelity and dose, as well as barriers and stimulants of interventions which ultimately translate into the impact of those interventions on innovation in governance.

\section{Process tracing}

\section{Stage 1. Collecting and developing the study material}

Various sources were utilised to obtain the quantitative and qualitative data necessary to build a theory as a way of tracing the processes associated with the evaluation of the selected ITIs as a case study. The field study involved:

- A comprehensive review of the literature on regional governance and innovation in governance; 
- An in-depth analysis of institutional and policy documents (e.g. legal acts, reports);

- Individual and collective interviews with stakeholder representatives in selected regions (personal, computer-assisted, telephone interviews);

- Other reference studies provided by the stakeholders (e.g. internal documents, such as reports, protocols, evaluation surveys, statements, notes, photo documentation).

The main limitation at this stage of was the fact that access was restricted to a selected representative group of individuals who were able to answer the study questions.

ITIs were considered to be the cause (A); thus, a change in sub-regional governance, here: in the context of ITIs governance, was the outcome (B) of the programme's intervention. An in-depth assessment using the process tracing method enabled the examining of the mechanisms, causes and links between them, that had led to specific outcomes following the implementation of ITIs. In the course of the study primary and secondary data was collected with a view to indicating the links between the ITI intervention (A) and the results in terms of innovation in sub-regional governance (B).

\section{Stage 2. Data analysis and formulating hypothetical causal mechanisms}

The study material obtained at the initial stage allowed the authors to formulate hypotheses regarding the causal links as a result of which the ITI implementation had contributed to a change in sub-regional governance while giving rise to some solutions with an innovative potential. Based on the evidence analysed, the second stage of the theory-building process tracing was conducted, during which the empirical material was examined with regard to the hypothesised causal mechanisms linking A and B. At that stage the authors posed key study questions along with accompanying working hypotheses:

1. The multilevel structure of ITI-based municipal governance processes encourages innovative solutions through the diffusion of knowledge and learning by different entities, including local and regional authorities

H.1.1. The adopted institutional formula of ITIs creates a new quality in the cooperation between stakeholders on the supra-local level

2. Europeanisation processes are the source of innovation in ITI-based sub-regional governance processes

H.2.1. Key stakeholders acquire new competences related to partner cooperation within ITI

H.2.2. Principles adopted under ITI take into account the requirements of "good governance" as a part of the European governance standards

3. The ITI formula is a pioneering solution with regard to the adaptation of imposed institutional standards

H.3.1. The implementation of ITI stimulates the creation of new services and / or products

In order to verify both the working and alternative hypotheses, a deductive approach with the following perspective was used: from general theoretical assumptions to their practical implementation in a specific context to explain a specific mechanism. 


\section{Stage 3. Operationalising the causal mechanisms}

Another stage of theory-building process tracing was to operationalise the causal mechanisms (Table 2).

Table 2. Operationalising the causal mechanisms

\begin{tabular}{|c|c|c|c|}
\hline Hypotheses & Independent variables & $\begin{array}{l}\text { Intervening causal } \\
\text { mechanisms }\end{array}$ & Dependent variables \\
\hline $\begin{array}{l}\text { H.1.1., H.2.1., } \\
\text { H.2.2. }\end{array}$ & $\begin{array}{l}\text { Culture of supra-local } \\
\text { cooperation }\end{array}$ & $\begin{array}{l}\text { Stakeholders decide } \\
\text { on an optimal ITI } \\
\text { formula (association or } \\
\text { agreement) }\end{array}$ & $\begin{array}{l}\text { Introducing the collegiality rule, } \\
\text { ensuring participation when } \\
\text { making decisions on ITI, ac- } \\
\text { countability for decisions taken }\end{array}$ \\
\hline $\begin{array}{l}\text { H.1.1., H.2.1., } \\
\text { H.2.2. }\end{array}$ & $\begin{array}{l}\text { Previous experienc- } \\
\text { es from cooperation; } \\
\text { degree of engagement of } \\
\text { entities from other sec- } \\
\text { tors, actions to encour- } \\
\text { age involvement of other } \\
\text { entities in the process } \\
\text { of ITI development and } \\
\text { implementation }\end{array}$ & $\begin{array}{l}\text { ITIs introduce new } \\
\text { coordination solutions } \\
\text { in the functional field }\end{array}$ & $\begin{array}{l}\text { Initiating cooperation between } \\
\text { local government units (LGUs) } \\
\text { and non-governmental organ- } \\
\text { isations (NGOs), businesses, } \\
\text { scientific community and other } \\
\text { parties wishing to be involved } \\
\text { in the work on the ITI strategy; } \\
\text { ensuring equal rights in the } \\
\text { decision-making process for all } \\
\text { participating entities, including } \\
\text { other than LGUs }\end{array}$ \\
\hline H.2.1., H.2.2. & $\begin{array}{l}\text { Existing legal regula- } \\
\text { tions; current political } \\
\text { situation; progressing } \\
\text { Europeanisation; impact } \\
\text { of the environment (in- } \\
\text { cluding local communi- } \\
\text { ty's social attitudes) }\end{array}$ & $\begin{array}{l}\text { ITI is a tool for im- } \\
\text { plementing the EU's } \\
\text { cohesion policy sup- } \\
\text { ported with funds to } \\
\text { implement projects }\end{array}$ & $\begin{array}{l}\text { Accepting pragmatism in ITI } \\
\text { programming; enabling all inter- } \\
\text { ested parties to participate; mul- } \\
\text { tilevel downstream and upstream } \\
\text { cooperation between levels; } \\
\text { improving management solu- } \\
\text { tions (internal communication, } \\
\text { transfer of knowledge, exchange } \\
\text { of know-how), political lobby- } \\
\text { ing, stakeholders' engagement in } \\
\text { a multi-sectoral dimension }\end{array}$ \\
\hline $\begin{array}{l}\text { H.1.1., H.2.1., } \\
\text { H.2.2. }\end{array}$ & $\begin{array}{l}\text { Culture of governance } \\
\text { at the supra-local level }\end{array}$ & $\begin{array}{l}\text { ITI is part of cohe- } \\
\text { sion policy and a tool } \\
\text { to support local and } \\
\text { regional development; } \\
\text { it is consistent with } \\
\text { municipal and region- } \\
\text { al policies adopted at } \\
\text { the national level; } \\
\text { ITI introduces new } \\
\text { standards in the field } \\
\text { of coordination in the } \\
\text { functional area that } \\
\text { refer to the principles } \\
\text { of "good governance" }\end{array}$ & $\begin{array}{l}\text { Defining frameworks for pos- } \\
\text { sible areas and projects; setting } \\
\text { directions for activities; adopting } \\
\text { a partnership model; orientation } \\
\text { towards the effectiveness of inter- } \\
\text { ventions undertaken; orientation } \\
\text { towards satisfying the needs of } \\
\text { cities and areas functionally asso- } \\
\text { ciated with them; } \\
\text { Democratic decision-making } \\
\text { processes, public consultations, } \\
\text { cooperation with partners from } \\
\text { various sectors, quality of public } \\
\text { information, adoption and imple- } \\
\text { mentation of codes of conduct }\end{array}$ \\
\hline
\end{tabular}




\begin{tabular}{|l|l|l|l|}
\hline H.2.1., H.2.2. & $\begin{array}{l}\text { Improving know-how; } \\
\text { improving the quality } \\
\text { of steering solutions, } \\
\text { including benchmark- } \\
\text { ing; implementing new } \\
\text { steering standards; us- } \\
\text { ing new ITC solutions; } \\
\text { increased awareness of } \\
\text { key actors involved in } \\
\text { the process }\end{array}$ & $\begin{array}{l}\text { ITI introduce new } \\
\text { in the functional field }\end{array}$ & $\begin{array}{l}\text { Active participation of local gov- } \\
\text { ernment units brought together } \\
\text { in the ITI association; changing } \\
\text { the existing relations between } \\
\text { local government units and } \\
\text { other entities operating under the } \\
\text { association; adjusting the LGUs' } \\
\text { own development strategies to } \\
\text { common objectives as defined by } \\
\text { the ITI strategy, participation of } \\
\text { LGU representatives in various } \\
\text { forms of education relating to } \\
\text { supralocal development goals; } \\
\text { formulating "tailor-made", } \\
\text { customised solutions for particu- } \\
\text { lar ITIs; changing/modifying } \\
\text { imposed standards; going beyond } \\
\text { the imposed limits }\end{array}$ \\
\hline H.3.1. & $\begin{array}{l}\text { Expectations of end } \\
\text { users }\end{array}$ & $\begin{array}{l}\text { ITI is a tool enabling } \\
\text { the delivery of new } \\
\text { services and products } \\
\text { in the indicated areas }\end{array}$ & $\begin{array}{l}\text { New solutions in the field of } \\
\text { transport and communica- } \\
\text { tion, modernization of existing } \\
\text { infrastructure, state-of-the-art } \\
\text { technological solutions related } \\
\text { to construction, environmental } \\
\text { protection }\end{array}$ \\
\hline
\end{tabular}

Source: Own elaboration.

\section{Stage 4. Assessing the inferential weight of evidence}

Testing hypotheses in process tracing is based on logical assumptions, meaning that the identified causal mechanism between A and B should be confirmed by evidence observed in the empirical material. Thus, the hypotheses testing process should rely on the examination of evidence to assess its weight, i.e. to what extent they confirm or deny the existence of the mechanisms between A and B (Punton, Welle, 2015a). This is the reason that the next stage in process tracing involved empirical tests which proved to be decisive in determining which evidence was necessary to confirm the causal mechanisms. The sources of evidence met or did not meet specific test criteria: straw-in-the-wind, hoop, smoking gun and/or doubly-decisive. It should be noted that the causal mechanism was confirmed only by the evidence that was positively verified by the doubly-decisive test (Table 3 ).

Table 3: Assessing evidence: four tests in process tracing

\begin{tabular}{|l|l|l|}
\hline Hoop tests & High (evidence is necessary for H) & Double decisive \\
\hline $\begin{array}{l}\text { Low (evidence } \\
\text { is insufficient } \\
\text { for H) }\end{array}$ & & $\begin{array}{l}\text { High (evidence is } \\
\text { sufficient for H) }\end{array}$ \\
\hline $\begin{array}{l}\text { Straw in the } \\
\text { wind tests }\end{array}$ & $\begin{array}{l}\text { Low (evidence is not necessary for } \\
\text { H) }\end{array}$ & Smoking gun tests \\
\hline
\end{tabular}

Source: Own elaboration based on: Punton, Welle, 2015b. 
H.1.1. The adopted institutional formula of ITIs creates a new quality in the cooperation between stakeholders at the supra-local level.

Test: Straw-in-the-wind

Evidence: Key findings from interviews on the ITI formula adopted by the various sub-regions were formulated a priori and then confirmed at the data collection stage. A number of factors were found to guarantee the optimal solution for a new quality in the cooperation between stakeholders at the supra-local level. That notwithstanding, account must be taken of the interviewees' subjective beliefs indicating their individual experiences, as well as the leaders'/policy-makers' attitudes which proved to be decisive in the adoption of the formally applicable formula of cooperation under the ITI.

Test result: Positive, although the example under investigation merely increases the credibility of the hypothesis but does not confirm it unequivocally.

Test: Doubly-decisive

Evidence: When interviewed individually, the respondents noted that the ITI gave rise to a new stage of cooperation in the functional area. Even if the ITI proved to be a modification of the already functioning supra-local relations (prior experience from cooperation), they had never been so specific and participatory nor had they ever referred so much to common projects. That mechanism was found to be the most promising in the current conditions. Such opinions are supported by the documents. The evidence represents a doubly decisive test as the interviewees' opinions are unique.

Test result: Positive: evidence indicates high confidence in the hypothesis.

H.2.1. Key stakeholders acquire new competences related to partner cooperation within ITI

Test: Straw-in-the-wind

Evidence: Based on the obtained data, it was found that ITI, through its institutional formula, forced somewhat new tasks from both the institutions involved and people. These were associated with the requirement to acquire new competences.

Test result: Positive, although this example increases the credibility of the hypothesis, but does not prove it in an unambiguous way. New institutional competences (e.g. being an intermediary institution) did not always correlate with the new competences of persons involved. In addition, ITI as a new mechanism supporting development only occasionally determined the development of specific forms supporting its functioning (e.g. training was provided as a standard, but with a few exceptions it had a typical, non-standard character).

\section{Test: Hoop}

Evidence: The analyzed documents show the experience of entities in the implementation of projects related to local development. At the same time, the interviews allowed the gaining of knowledge about new competences acquired along with the implementation of the ITI strategy. If the evidence suggested that the entities involved do not possess and do not acquire new experiences and competences, this would seriously weaken the hypothesis. 
Test result: Ambiguous, because the analysis of analyzed case studies indicates the presence of the necessary causal condition. One cannot, without having previous experience and related competences, manage EU projects (here in the ITI formula). At the same time, each new experience (and ITI is such an experience) forces the acquisition of new competences.

Test: Doubly-decisive

Evidence: The specific nature of ITI was noted: for formal reasons (ITI receives the status of an Intermediate Body) and informal (a new system of relations, influence, power) and a collective process in which both collectives (e.g. municipal representatives) as well as individuals, indicates the need to open up to new knowledge and new experiences. Acquiring new competences is a consequence of this requirement. New competences, both institutions and people, are also exchanged by interviewees.

Test result: Positive: evidence has high power confirming the hypothesis.

H.2.2. Principles adopted under ITI take into account the requirements of "good governance" as a part of the European governance standards

Test: Straw-in-the-wind

Evidence: During interviews, interlocutors often referred to the principles of "good governance": openness, participation and efficiency. However, the above evidence does not meet the criterion of necessity or certainty. The low level of certainty of this proof is due to the fact that the specific contents that connect with the understanding of these principles (the interlocutors do not define them) and the way they translate into the practice of ITI are not completely known (only one of the examined ITIs) developed a standard that can be defined as the "ITI Code of Conduct"; the remaining ITIs refer to subjective opinions and experiences). It is also impossible to verify the opinions of stakeholders other than the ITI managers on the principles and values of the ITI. In addition, the interviewees refer to only the selected (they do not state, according to what key) values that constitute "good governance" (e.g. they omit the issue of accountability, transparency).

Test result: Positive, although the evidence provides an explanation without final settlement.

Test: Smoking gun

Evidence: "Good governance" means the cooperation of stakeholders who-in pursuit of common value - are guided by principles derived from different codes of values. It can be assumed that in the case of the EU solution, which is ITI, they should refer to the principles of the European Union. The analysis of documents shows that on key issues (e.g. ITI strategies), the desired rules have been saved. Interviews, however, provided knowledge that even if the coveted values are known, in institutional practice so far they only sometimes took root.

Test result: Negative: the hypothesis cannot be confirmed.

Test: Doubly-decisive

Evidence: The analyzed ITIs have solutions supporting the democratic nature of the decisions made (usually each entity - regardless of its size - has one vote). In addition, it was 
found that some larger centres gave up the possibility of being a ZIT headquarters for a smaller city in the functional area. Some have also adopted non-obligatory codes of conduct. Regardless, the interviews provided evidence of the existence and implementation of some principles related to the EU idea of "good governance". At the same time, it turned out that these are the principles chosen in a subjective and often unconscious way.

Test result: Ambiguous: at the same time, the test was able to distinguish between evidence that supports the hypothesis and its alternatives.

H.3.1. The implementation of ITI stimulates the creation of new services and / or products

Test: Straw-in-the-wind

Evidence: The participants of individual interviews recalled examples of innovative solutions within the implemented projects. At the same time, they emphasized that these are not innovations as such, because they already function as a standard in Western Europe, but in Polish conditions they can be treated as innovative. Additionally, it was emphasized that the legislator did not treat ITI as a mechanism generating innovative solutions, but rather limited itself to securing basic and urgent needs. Regardless of this, the actions taken in this respect took into account the elements of innovative solutions.

Test result: Ambiguous: the existing evidence is neither unique nor certain and has no meaning for both confirmation and rejection of the hypothesis.

Test: Hoop

Evidence: Analysis of existing documents shows that programmed projects guarantee obtaining innovative solutions in the dimension of products and services. Nevertheless, the interviewees emphasize that the assumed "innovative character" of these solutions is contractual and contextual: in Poland solutions are innovative, in the West of Europe they should be treated as a standard.

Test result: The collected evidence positively passed the test: the result is certain, but it is not unique.

Test: Doubly-decisive

Evidence: In interviews, interviewees stressed that the project application procedure was launched, therefore only ex-ante evaluation is possible at this stage. The review of planned projects implies innovative solutions not seen in individual regions so far, e.g. in ITI ŁMAA it is planned to build public kindergartens in passive house technology, in ZIT WFA, an agglomeration of cycle routes will be created, in ITT CSS thermal insulation will be applied to schools and other public buildings, or public spaces will be created, the shape of which has been decided by the residents. The hypothesis was also verified by other evidence, e.g. interviews with potential project promoters and recipients of planned services / products.

Test result: Positive. Existing evidence is unique and highly reliable to confirm the hypothesis. 


\section{Stage 5. Conclusions from process tracing}

In summing up the process tracing exercise, emphasis should be placed on the certainty of the various elements of the causal mechanisms based on the evidence collected and tests performed. The result achieved from the examination of the selected ITIs in the context of innovative governance solutions may be shown as follows (Table 4):

Table 4. Interpretation of results of tests verifying the hypotheses

\begin{tabular}{|l|l|}
\hline Intervening causal mechanisms & $\begin{array}{l}\text { Accepted (there is sufficient evidence to show } \\
\text { that the researcher is certain that cause A led } \\
\text { to outcome B in the process described in the } \\
\text { mechanism) }\end{array}$ \\
\hline $\begin{array}{l}\text { Stakeholders decide on an optimal ITI formula } \\
\text { (association or agreement) }\end{array}$ & RATHER YES \\
\hline $\begin{array}{l}\text { ITIs introduce new coordination solutions in } \\
\text { the functional field }\end{array}$ & DEFINITELY YES \\
\hline $\begin{array}{l}\text { ITI is a tool for implementing the EU's cohe- } \\
\text { sion policy supported with funds to implement } \\
\text { projects }\end{array}$ & YES \\
\hline $\begin{array}{l}\text { ITIs introduce new coordination solutions in } \\
\text { the functional field which are based on the } \\
\text { rules of good governance }\end{array}$ & RATHER YES \\
\hline $\begin{array}{l}\text { ITI is part of cohesion policy and a tool to } \\
\text { support local and regional development; it is } \\
\text { consistent with municipal and regional policies } \\
\text { adopted at the national level }\end{array}$ & RATHER YES \\
\hline $\begin{array}{l}\text { ITI is a tool that makes it possible to deliver } \\
\text { innovative services and products }\end{array}$ & YES \\
\hline
\end{tabular}

Source: The author's own study.

\section{Results: quality and extent of intervention}

In order to determine a causal mechanism, the most important existing elements, processes and outcomes should be observed and analysed when building a theory of change with particular focus on fidelity and dose which ultimately translate into the impact of those interventions on innovation in sub-regional governance.

The fidelity of an intervention refers to the degree of its implementation with regard to the ex-ante assumptions. The evaluation of fidelity accounts for the effects of the causes. Referring to A. V. Dane and B. H. Schneider (1998), the following aspects of intervention fidelity can be distinguished:

- Adherence: the various parts of the intervention are implemented according to the assumptions: based on the available resources and the context, a number of ITI-related actions directed to various stakeholder groups were identified during the study with the authors focusing on those that bore the features of innovation;

- Exposure: the substantive scope of intervention addressed to stakeholders; having access to relevant resources made it possible to diagnose the actions taken to reinforce innovation in the governance of the functional areas in the ITI formula assuming stakeholders' participation and co-decision; 
- Quality of the delivery: Ideal objective in building a theory of change; the study showed a consistent achievement of activity cohesion, delivery of products and services with features of innovation in the governance of functional areas under the ITI formula;

- Participant responsiveness: determining, in the context of actions being performed, whether stakeholders have used the intervention in a pre-defined manner; in the case of the ITIs under investigation, the stakeholders were observed to be directly involved in generating and implementing innovations in the governance of functional areas under the ITI formula;

- Differentiation: unique features of an intervention; in the case of the present study, the intervention was found to have features that made it special, unusual and unique as compared to other interventions, including its possible scenarios.

Additionally, when assessing intervention fidelity with regard to the governance of functional areas under the ITI formula, the authors established the following:

- The way the intervention was designed (including the concept of optimal institutional formula, constellation of the entities involved, leadership roles, mutual obligations, participations, openness of the authorities) and the way it was implemented (democratic decision making, quality of communication and information, performance of mutual obligations, pursuit of excellence);

- Integrity and distinctiveness of the mechanisms, processes and innovation dissemination in regional governance: action strategy, internal and external resources, prior experience in similar actions;

- Consolidation and impact of innovation in regional governance: impact on the community in the context of resources, contents and relations.

The extent of intervention refers to the quantity, frequency and duration of an intervention aimed at making a change in the outcome. It is helpful in understanding how many constituent interventions are needed to achieve the desired results. It is also a key component of fidelity. The extent of interventions concerning innovation in sub-regional governance has many dimensions. Basically, it is determined in order to indicate stimulants and barriers in the operation of ITIs in Poland, which can be referred to as innovation in functional area upon governance (Table 5).

Table 5. Innovation stimulants and barriers in ITI-based sub-regional governance

\begin{tabular}{|l|l|l|l|}
\hline Stimulants & Feature & Interpretation & Example \\
\hline & network & no hierarchy & $\begin{array}{l}\text { Each of the entities has one vote; each } \\
\text { vote is of the same value (all ITIs in } \\
\text { question) }\end{array}$ \\
\cline { 2 - 4 } & trust & $\begin{array}{l}\text { key component of human } \\
\text { capital }\end{array}$ & $\begin{array}{l}\text { key relevance for the effectiveness of } \\
\text { local systems (ITI CSS) }\end{array}$ \\
\cline { 2 - 4 } & $\begin{array}{l}\text { participation in } \\
\text { including stakeholders } \\
\text { other than public sector } \\
\text { representatives }\end{array}$ & $\begin{array}{l}\text { establishing a Consultation Council, as } \\
\text { the Association's advisory body, con- } \\
\text { sisting of stakeholder representatives } \\
\text { of sectors other than the public sector } \\
\text { (non-governmental organisations, busi- } \\
\text { ness, science) (ITI CSS) }\end{array}$ \\
\hline
\end{tabular}




\begin{tabular}{|c|c|c|c|}
\hline & $\begin{array}{l}\text { professionalism } \\
\text { in ITI manage- } \\
\text { ment }\end{array}$ & $\begin{array}{l}\text { new, increasingly advanced } \\
\text { and improved techniques } \\
\text { of managing units and } \\
\text { processes, quality improve- } \\
\text { ments }\end{array}$ & $\begin{array}{l}\text { cooperation with municipal and dis- } \\
\text { trict ITI coordinators, series of expert } \\
\text { meetings to exchange good practices } \\
\text { and innovative solutions in ITI project } \\
\text { implementation (ITI CSS) }\end{array}$ \\
\hline & $\begin{array}{l}\text { integrity of } \\
\text { policies }\end{array}$ & $\begin{array}{l}\text { linking national policies } \\
\text { to European and regional } \\
\text { policies }\end{array}$ & ITI strategies (all analysed ITIs) \\
\hline & partnership & $\begin{array}{l}\text { cooperative relations be- } \\
\text { tween the regional govern- } \\
\text { ment, and sub-regional and } \\
\text { local governments }\end{array}$ & $\begin{array}{l}\text { process designed to seek both effective- } \\
\text { ness and public value (improvement of } \\
\text { the citizens' quality of life, increased } \\
\text { comfort, quality and satisfaction) (CSS); } \\
\text { more control being handed over from } \\
\text { the higher level (regional government) } \\
\text { to the intermediate level (sub-region) } \\
\text { and from the intermediate level to the } \\
\text { local level; decentralisation of compe- } \\
\text { tences and implementation of partici- } \\
\text { patory management tools, particularly } \\
\text { where local community participation } \\
\text { is essential (actions associated with } \\
\text { revitalisation) (ITI MA GGS). }\end{array}$ \\
\hline & $\begin{array}{l}\text { comprehensive- } \\
\text { ness of interven- } \\
\text { tions }\end{array}$ & $\begin{array}{l}\text { shifting from a single event } \\
\text { model to multiple processes } \\
\text { and phenomena that form } \\
\text { new patterns, goods, tech- } \\
\text { nologies in production and } \\
\text { services }\end{array}$ & $\begin{array}{l}\text { linking the labour market policy and } \\
\text { education policies, utilising modern } \\
\text { construction methods and technologies } \\
\text { (e.g. new nursery schools constructed in } \\
\text { the passive building technology in ITI } \\
\text { ŁMAA) }\end{array}$ \\
\hline Barriers & & & \\
\hline & $\begin{array}{l}\text { no possibility to } \\
\text { reject "top-down } \\
\text { constructivism" }\end{array}$ & $\begin{array}{l}\text { no consultation regarding } \\
\text { the ITI formula at the stage } \\
\text { of development of national } \\
\text { solutions }\end{array}$ & $\begin{array}{l}\text { strong hierarchy and bureaucracy } \\
\text { which limits the possibility of creation } \\
\text { of tailor-made solutions }\end{array}$ \\
\hline & $\begin{array}{l}\text { poor involve- } \\
\text { ment of stake- } \\
\text { holders from } \\
\text { sectors other } \\
\text { than the public } \\
\text { sector }\end{array}$ & $\begin{array}{l}\text { no potential, resources and } \\
\text { interest of representatives of } \\
\text { other sectors that are signif- } \\
\text { icant for the development } \\
\text { of regional / sub-regional / } \\
\text { municipal policy }\end{array}$ & $\begin{array}{l}\text { NGOs are mostly not treated as } \\
\text { partners due to their deficits in basic } \\
\text { resources }\end{array}$ \\
\hline & $\begin{array}{l}\text { long-term part- } \\
\text { nership "incuba- } \\
\text { tion" }\end{array}$ & $\begin{array}{l}\text { prolonged period of } \\
\text { establishing cooperative } \\
\text { relations which delayed the } \\
\text { possibility of starting work } \\
\text { on creating the right solu- } \\
\text { tions with possible innova- } \\
\text { tive potential }\end{array}$ & $\begin{array}{l}\text { lack of understanding for the 'common } \\
\text { good', the intention to gain funds for } \\
\text { one's own purposes only }\end{array}$ \\
\hline & temporary effect & $\begin{array}{l}\text { the durability of solutions } \\
\text { developed in the ITI formu- } \\
\text { la is not secured after the } \\
\text { end of financing in the cur- } \\
\text { rent financial perspective }\end{array}$ & $\begin{array}{l}\text { ITIs are not supported by legislation, } \\
\text { they are going to break up with the end } \\
\text { of the EU financing within 2014-2020 } \\
\text { scheme }\end{array}$ \\
\hline
\end{tabular}




\section{Conclusion}

The aim of the analysis was to identify the innovative governance specified during ITIs implementation. It was planned to establish what are the dominant modes of sub-regional governance and what is the role and importance of institutional actors in the process of ITIs governance. An important task was also to determine what are their new competences linked to the ITIs implementation and if are there any new products/services related to innovation in sub-regional governance. Finally, it was important to check whether ITIs should consider principles of "good governance" as one of the key factors of innovative governance arrangements.

Integrated Territorial Investments constitute an innovation in the EU cohesion policy: for the first time from the Community perspective, tools for shaping the policy of developing functional areas of cities at the supra-local level have been transferred. The interpretation of these arrangements in Polish conditions, institutionalized at the national level, shows the character of adaptive innovation: designed and implemented activities under ITI are a response to formal requirements set by the European Commission to individual Member States. ITI is a formal element of regional development policy and is included in regional operational programs. Unfortunately, this is not a solution that has been integrated in the implementation processes of regional development strategies. In the selected regions, even if there had been consultations at the level of individual ITIs with the European Commission, the finally negotiated institutional arrangements do not fully respond to the real needs of the region.

When assessing the quality of ITIs as an innovation in governance, it was observed that respondents appreciate the scope and scale of implementing integrated activities in the functional areas of cities. In some cases (ITT CSS) they are a consequence and continuation of previously started activities, and in others (ITI MA GGS) another attempt to institutionalize cooperation at the supra-local level. There are regions in which ITIs initiated cooperation between local government entities in the sub-region (ITI MA ŁMAA), and those where a narrow, formal-pragmatic approach to ITIs implementation was applied, without in-depth reflection regarding a longer time frame (ITI WFA). The scale of intervention shows that all formally authorized entities (local governments) were involved in the process of ITIs implementation. However, the scale of involvement of individual entities and the various impacts on decisions are different. The mentoring model is dominant, in which the strongest entity (usually a provincial city, a metropolitan centre) is the driving mechanism of activities within ITIs (office location, initiating activities, chairing, proposing solutions). This is the case, among others in the following cases: ITI MA GGS, ITI MA ŁMAA and ITI WFA. Even if all entities formally have equal status, the leader is one and he sets the tone of cooperation in the sub-regional dimension. The only exception is the participative model, where there are several equal entities giving a tone of debate within ITIs, and the majority of union members actively participate in it (ITT CSS). Considering activities related to the ITIs implementation, one observes a network of entities participating in it. There is no formal hierarchy in it, even if the authorities of established unions and agreements were chosen democratically as formal organizations. Trust between actors is crucial to the effectiveness of local systems. One of the elements of strengthening this trust is the establishment of consulting councils as advisory bodies, which include representatives of stakeholders representing sectors other than only 
public (non-governmental organizations, business, science). This strengthens the aspect related to the implementation of tasks related to ITIs projects. Governance in this case counts with a kind of own dynamics: because the accepted patterns are the answer to the problems that need to be resolved without including traditional institutions, the more willingly they are used. It is worth emphasizing that the combination of decisions that are taken by organizations implementing ITIs results from a deep connection of national policies with policies at the European level and with regional policies. Thus, the adopted governance model proved to be a melting pot of traditional forms of administration and network cooperation with a wide participation of stakeholders that effectively addresses this challenge. The grass-roots approach takes into account the specificity of particular sub-regions, effectively strengthens the consistency of decisions, improves the quality of governance and contributes to the strengthening of social capital in local communities, and motivates the using of innovative solutions in the development of individual functional areas.

The governance process through the ITIs implementation in the selected sub-regions was designed in partnership activities between the regional self-government and local self-governments. It has been constructed in such a way as to strive both to achieve both efficiency and public value (improving the living conditions of residents, increasing comfort, quality and a sense of satisfaction). It is characterized by increased transfer of control through the upper level (regional self-government) to the intermediate level (sub-region) and this to the local community (participation of final stakeholders), decentralization of competences and the introduction of participative tools, especially where the participation of residents is a key (e.g. activities related to revitalization). The process can be considered as a process of creative destruction, leading to changes in the organization and methods of managing social phenomena. It violates well-established patterns of consumption and production. Implementation of jointly defined projects takes place by establishing a new institutional structure, where desirable techniques are to secure democratic legitimacy through cooperation mechanisms, systemic inclusion of social entities, taking into account other levels of management in the public sector (mainly regional) and systematic and regular communication, information exchange and improving and improving competence as a central function. The governance process takes account of key regional policy variables in the economic and political dimension (including strategic planning, implementation of comprehensive investment projects, supporting economic development), socio-political aspects (including development of social services, improving the qualifications of residents, cultural policy and culture development, migration), institutional and political issues (including the quality of life, development of public participation, strengthening democratic procedures, solving sectoral problems, e.g. in the areas of: health, public services, education, public safety, coordination of development policies through cooperation and partnership), spatio-political questions (e.g. infrastructure and public utilities, development of public transport, investment areas, revitalization of cities and protection of cultural heritage, neighbourhood areas), environmental and political elements (including sustainable development, care for the potential of natural resources, integrated approach to the environment, renewable energy sources, spatial planning with respect for the principles of eco-development and implementation of initiatives for the environment). 
The effect of governance at the sub-regional level under the ITIs formula is a comprehensive perception of planned interventions that departs from individual events to a complex of processes and phenomena that create new patterns, goods, technologies in the spheres of production and services. Innovative activities undertaken take place both in a specific space and in the system of connections, i.e. the created innovative system, which includes adopted organizational solutions. They assume striving to find solutions to real problems by rejecting the possibility of top constructivism. It is connected with the conviction of the necessity of observing democratic values and standards as guarantors of social order, in particular in the scope of reaching universal standards such as: partnership, cooperation, professionalism, political neutrality, honesty, avoiding a conflict of interests. In addition, the constructed model of governance through the implementation of ITI in the central sub-region takes into account different dimensions, ranges, areas and levels of administration. Thus, it can be a model and reference point according to which it should be organized and function.

Assessing the extent of innovation in governance, it can be concluded that ITIs have the potential to materialize the concept of territorial governance currently under discussion in Western Europe. Unfortunately, it has a relatively small scope: part of the native discourse refers to already outdated content that translates into practical solutions within ITI (e.g. smart city 2.0, while smart city 3.0 and 4.0 are currently being implemented in the Western European regions). The discourses regarding the normative governance dimension ("good governance") are also unknown, and even more so they do not translate into practical solutions (e.g. none of the ITIs examined has found an existing and practically respected code of ethics). Inter-sectoral cooperation is poorly institutionalized: representatives of the business sector and non-governmental organizations rarely meet the formal requirements to become a beneficiary of financing projects submitted by them. Even if they are invited to advisory and consultative bodies, they do not affect the final decisions.

Respondents are aware that programmed services and products, even if they are referred to as "innovative", do not always meet the requirement of innovative solutions. They emphasize that "most of them are a novelty in Poland, however, in the Western Europe they have been operating for 30 years" (Local government representative in ITI MA ŁMAA). The limitation for the implementation of innovative services and products that would match the solutions currently sought is, on the one hand, the real opportunities offered by ITI, and on the other - the need to secure the basic needs of specific areas and catch up in this area.

As a conclusion, one can state that it, is a source of innovation in sub-regional governance in Poland which has become an institutional tool supporting the process of Europeanisation, Additionally, one concerns the positive impact of multilevel governance processes on the generation of innovations in institutional arrangements. However, the observed causal mechanisms showed the adoptive nature of innovations generated in analyzed ITIs. Moreover, they had top-down direction and only rarely were open toward cross-sectoral co-operation. Nevertheless, even if they did not fully meet the ideal model of innovations in governance, they resulted in a set of innovatory solutions, pioneering, unparalleled and unique in Polish conditions. 


\section{References:}

Anheier H., Korreck S. (2013), Governance Innovations. Hertie School of Governance. The Governance Report 2013. Oxford: Oxford University Press, 83-116.

Beach D., Pedersen R.B. (2013). Process-Tracing Methods: Foundations and Guidelines. Michigan: University of Michigan Press.

Collier D. (2011). 'Understanding Process Tracing'. PS: Political Science and Politics. Vol. 44, No. $4,823-830$.

Dane A.V., Schneider B.H. (1998). 'Program integrity in primary and early secondary prevention: are implementation effects out of control?.' Clinical Psychology Review. No. 18, 23-45.

Fitzpatrick J. L., Sanders J. R. Worthen B. R. (2011). Program Evaluation: Alternative Approaches and Practical Guidelines. London: Pearson Education.

George A. L., Bennett A. (2005). Case Studies and Theory Development in the Social Sciences. Cambridge, MA/London: MIT Press.

Klimowicz M., Dudzik L. (2015). Zintegrowane Inwestycje Terytorialne w nowym podejściu do zarzadzania miastami $w$ ramach realizacji unijnej polityki spójności. In: A. Wiktorska-Święcka (ed.). (Re)organizacja $w$ zarządzaniu miastami $w$ Polsce $w$ kontekście wyzwań rozwojowych. Wrocław: Oficyna Wydawnicza ATUT, 107-123.

Punton M., Welle K. (2015a). Applying Process Tracing In Five Steps. Practice Paper No.10. April. Institute of Development Studies.

Punton M., Welle K. (2015b). Straws-in-the-wind, hoops and smoking guns: What can process tracing offer to impact evaluation?. Practice Paper No.10. April. Institute of Development Studies.

Sale J.E.M., Lohfeld L.H., Brazil K. (2002). 'Revisiting the quantitative-qualitative debate: Implications for mixed-methods research'. Quality \& Quantity. Vol. 36, No.1, 43-53.

Van Evera S. (1997). Guide to Methods for Students of Political Science. Ithaca, NY: Cornell University Press.

Wiktorska-Święcka A., Michalewska-Pawlak M., Klimowicz M. (2017a). Innowacje we współzarządzaniu rozwojem regionalnym. Praktyka instytucjonalna $w$ wybranych regionach w Polsce. Warszawa: Oficyna Wydawnicza ASPRA.

Wiktorska-Święcka A., Michalewska-Pawlak M., Klimowicz M. (2017b). Institutional determinants of innovation in regional governance in Poland. Warszawa: Oficyna Wydawnicza ASPRA. 